\title{
INTERNATIONAL TOURISM
}


INTERNATIONAL TOURISM

An Economic Perspective

\section{François Vellas}

and

\section{Lionel Bécherel}

Foreword by Eduardo Fayor-Solá

Director of Education and Training World Tourism Organisation, Madrid 
ISBN 978-0-333-61523-2 ISBN 978-1-349-24074-6 (eBook)

DOI 10.1007/978-1-349-24074-6

INTERNATIONAL TOURISM

Copyright (C) 1995 by François Vellas and Lionel Bécherel

Foreword copyright (C) 1995 by Eduardo Fayor-Solá

Softcover reprint of the hardcover 1st edition 1995 978-0-333-61522-5

All rights reserved. No part of this book may be used or reproduced in any manner whatsoever without written permission except in the case of brief quotations embodied in critical articles or reviews.

For information, address:

St. Martin's Press, Scholarly and Reference Division, 175 Fifth Avenue, New York, N.Y. 10010

First published in the United States of America in 1995

ISBN 978-0-312-12723-7

Library of Congress Cataloging-in-Publication Data

Vellas, François.

International tourism / François Vellas and Lionel Bécherel. -

1 st ed.

p. $\mathrm{cm}$.

Includes bibliographical references and index.

ISBN 978-0-312-12723-7

1. Tourist trade. I. Bécherel, Lionel. II. Title.

G155.A1V453 1995

338.4'791-dc20 


\section{Contents}

List of Tables xii

List of Figures $\quad$ xv

List of Boxes xvii

Acknowledgements xviii

List of Abbreviations xix

Foreword by $\mathrm{Dr}$ Eduardo Fayos-Solá $\quad \mathbf{x x}$

Introduction xxii

1 Definitions and Trends in International Tourism 1

Definitions 1

The domestic visitor 3

The international visitor 3

The international tourist 5

The excursionist or same-day visitor $\quad 7$

Accounting and economic indicators in international tourism 7

Statistical sources $\quad 8$

OECD tourism accounts systems 9

Economic indicators for international tourism 11

International tourism trends $\quad 13$

World and regional tourism trends $\quad 15$

International tourism flows and the level of economic

development 19

The main destinations $\quad 20$

References 23

Further reading $\quad 24$

2 The International Tourism Market in the Destinations of the World 25

International tourism demand in Europe 26

International tourist arrivals $\quad 27$

Tourism receipts 28

The main European destinations 29

International tourism demand in the American region 31

International tourist arrivals $\quad 31$ 
Tourism receipts $\quad 35$

The main American destinations $\quad 36$

International tourism demand in Africa 38

International tourist arrivals $\quad 39$

Tourism receipts $\quad 40$

The main African destinations $\quad 41$

International tourism demand in the Middle East $\quad 44$

International tourist arrivals $\quad 44$

$\begin{array}{ll}\text { Tourism receipts } & 47\end{array}$

The main Middle Eastern destinations $\quad 48$

International tourism demand in the South Asia region 49

International tourist arrivals $\quad 50$

Tourism receipts $\quad 51$

The main South Asian destinations 53

International tourism demand in the East Asia and Pacific

region $\quad 54$

International tourist arrivals $\quad 55$

Tourism receipts $\quad 56$

The main East Asian and Pacific destinations 58

Further reading $\quad 62$

3 The Theoretical Economic Determinants of International

$\begin{array}{ll}\text { Tourism } & 63\end{array}$

The theory of factor endowments and international tourism $\quad 64$

Factor endowments in international tourism 65

The theory of factor endowments $\quad 68$

The theory of factor endowments in international tourism 73

Limitations of international tourism factor endowments $\quad 75$

The theory of comparative costs and international tourism $\quad 76$

The theory of comparative costs $\quad 76$

The role of comparative costs in international tourism $\quad 79$

Exchange rates and comparative advantage $\quad 81$

The theory of absolute advantage and technological advance $\quad 85$

The theory of demand $\quad 86$

The theory of demand $\quad 86$

The role of demand in international tourism 88

References $\quad 94$

Further reading $\quad 94$

4 Supply in the Accommodation Sector 96

The hotel trade in the world 97

Growth in the number of rooms from 1987 to 1992 
Hotel supply in Europe $\quad 98$

Hotel supply in the Americas 99

Hotel supply in Africa 101

Hotel supply in Asia 101

Hotel chains $\quad 102$

Hotel consortia $\quad 102$

Integrated hotel chains $\quad 103$

Hotel franchising $\quad 105$

Club Méditerranée $\quad 106$

$\begin{array}{ll}\text { Tourism lodgings } & 107\end{array}$

$\begin{array}{ll}\text { Second homes } & 108\end{array}$

Furnished rented accommodation $\quad 110$

Restaurant chains 113

References $\quad 117$

$\begin{array}{ll}\text { Further reading } & 117\end{array}$

5 Air Transport and Tourism 119

$\begin{array}{ll}\text { International air transport demand } & 121\end{array}$

The international air transport market $\quad 121$

International non-scheduled air traffic $\quad 122$

$\begin{array}{ll}\text { Airline companies } & 124\end{array}$

Ranking airline companies $\quad 125$

The geographic distribution of airline companies $\quad 128$

The North American region $\quad 129$

The European region $\quad 129$

The Asia-Pacific region $\quad 130$

The Latin American region $\quad 130$

The African and Middle Eastern region $\quad 131$

Cost structures of airline companies $\quad 131$

Comparing cost structures of scheduled and charter airlines 131

Direct operating costs 133

Indirect operating costs $\quad 134$

Labour costs $\quad 134$

The fleet of airline companies $\quad 136$

Deregulation and international competition 138

The 'Open Skies' policy and the United States 140

Air transport liberalisation in EU countries 142

$\begin{array}{ll}\text { Strategies adopted by airline companies } & 144\end{array}$

Mergers, acquisitions and market concentration $\quad 144$

Partnership agreements $\quad 146$

Diversification strategies $\quad 150$

Privatisation strategies $\quad 151$ 
The role played by air transport in international tourism development

Comparative international analysis of the air transport and tourism sector

Problems of equipment and infrastructure associated with international tourism development

References

Further reading

6 Selling and Marketing the Tourism Product

The tourism product market

Definition of the tourism package

The classification of tourism packages

Economic characteristics of tourism products 165

Tour operators

Definition

Tour operators in the world

Tour operators in Switzerland, the Netherlands and

Scandinavia

Packaging the tourism product

Market research

Negotiating contracts with different suppliers of tourism services

Designing the product

Negotiating the package

Finalising international contracts

Selling and marketing the product

The brochure

Marketing by travel agencies

Advertising and promotion

Global distribution systems

Definitions

The main GDS

The problems of GDS regulation

Strategies to improve the use of GDSs in developing countries

Further reading

7 Finance and Investment in International Tourism 
Investment appraisal $\quad 198$

Return on investment 198

Payback 199

Discounted cashflow or net present value 199

Sources of finance $\quad 202$

Equity finance $\quad 202$

Loans 202

Leasing $\quad 202$

Lease back $\quad 204$

International financing and investment aid 204

The characteristics of investment grants 205

The different types of grants 205

Sources of international financing $\quad 208$

Financing of European projects $\quad 210$

References $\quad 216$

Further reading $\quad 216$

8 The Economic Impact of Tourism 217

International tourism and employment $\quad 217$

The characteristics of employment in the different branches $\begin{array}{ll}\text { of tourism } & 218\end{array}$

Trends in employment $\quad 220$

$\begin{array}{ll}\text { Employment and human resources } & 221\end{array}$

$\begin{array}{ll}\text { Training in the tourism industry } & 221\end{array}$

Tourism and economic development $\quad 224$

Macroeconomic policies of tourism development 225

The objectives of tourism policies 225

The resources necessary for the implementation of tourism policies $\quad 227$

The tourism multiplier $\quad 229$

The ecological and socio-cultural effects of international tourism

The ecological effects $\quad 235$

The socio-cultural effects $\quad 238$

Tourism and international trade $\quad 239$

Trends in international trade and international tourism 239

Imports in tourism consumption $\quad 242$

$\begin{array}{ll}\text { The balance of payments } & 244\end{array}$

Balance of payments and tourism 244

Methods of integrating tourism transactions in the balance of payments: tourism transactions and current account transactions 
The economic importance of tourism in the balance of payments

References

252

Further reading

252

9 Tourism Organisations and Tourism Policies

Tourism organisations $\quad 253$

National public sector tourism organisations $\quad 254$

National professional organisations $\quad 256$

The World Tourism Organisation (WTO) 257

Intergovernmental organisations partially responsible for tourism

Non-governmental international organisations

The General Agreement on Trade and Services and tourism policy

Tourism elements in GATS

The liberalisation process - reducing trade barriers 266

Benefits of GATS to tourism

Promotional policies in international tourism

Tourism promotion campaigns

Promotional expenditure abroad

The effectiveness of tourism promotion policies $\quad 274$

Tourism policies, planning and land development $\quad 274$

Tourism development methods $\quad 276$

Tourism site development $\quad 278$

$\begin{array}{ll}\text { Social tourism policies } & 281\end{array}$

International tourism policies and public health 283

International tourism and health risks 283

Health tourism products - international tourism and improvement in health standards $\quad 289$

References $\quad 291$

Further reading $\quad 292$

10 International Tourism in Industrialised Countries 293

Tourism policies and strategies in OECD countries 294

International tourism policies in Austria 294

International tourism policies in Spain $\quad 297$

International tourism policies in the United States 299

International tourism policies in France 301

International tourism policies in the United Kingdom 305

Tourism strategies and policies of the European Union 309

Free movement and the protection of tourists 309 
Working in the European tourism industry 310

Transport and tourism $\quad 310$

Regional development and tourism 311

References $\quad 312$

Further reading $\quad 312$

11 International Tourism in Developing Countries 313

The features of international tourism in developing countries 313

The impact of international tourism in developing countries 316

The economic impact of international tourism 318

The socio-cultural impacts 323

The environmental impacts 325

Tourism development policies in developing countries 328

Tourism promotion and the matching of demand 328

New tourism products and the modernisation of the supply 330

Adaptation of air transport to the development of tourism 331

Facilitation and installation rights 333

Training $\quad 334$

References $\quad 336$

Further reading 336

12 Trends and Forecasts of International Tourism 337

WTO forecasts for international tourism 338

WTO forecasts for European, American and East Asian-

Pacific tourism 340

Forecasts for the European region 341

Forecasts for the American region 342

Forecasts for the Asia-Pacific region $\quad 344$

The predicted trends in tourism development policy 345

More competitive quality-price ratio and better

productivity $\quad 345$

Diversification of tourism products 347

Stronger economic effects of tourism 348

References $\quad 350$

$\begin{array}{ll}\text { Further reading } & 350\end{array}$

$\begin{array}{ll}\text { Index } & 351\end{array}$ 


\section{List of Tables}

1.1 The cost of living on holiday

1.2 International tourist arrivals and receipts worldwide, 1970-93

1.3 International tourist arrivals and receipts worldwide, 1985-93

1.4 International tourist arrivals and receipts classified according to the World Bank groups of countries in 199120

1.5 World's top tourism earners (international tourism receipts)

1.6 World's top tourism spenders 1international tourism expenditures)

2.1 International tourist arrivals and receipts in Europe, 1970-93

2.2 International tourism in Europe, 1992

2.3 International tourist arrivals and receipts in the Americas, 1970-93

2.4 International tourism in the Americas, 1992

2.5 International tourist arrivals and receipts in Africa, 1970-93

2.6 International tourism in Africa, 1992

2.7 International tourist arrivals and receipts in the Middle East, 1970-93

2.8 International tourism in the Middle East, 1992

2.9 Average annual growth rates, 1983-93 49

2.10 International tourist arrivals and receipts in South Asia, 1970-93

2.11 International tourism in South Asia, 1992

2.12 International tourist arrivals and receipts in East Asia and the Pacific, 1970-93

2.13 Tourism and international trade in East Asia and the Pacific, 1985-92

2.14 International tourism in East Asia and the Pacific (EAP), 1992

3.1 Comparative advantages 78

3.2 Trends in exchange rates $\quad 82$

3.3 Nominal exchange rate against the dollar 83

3.4 International tourism receipts and expenditure, $1992 \quad 84$ 
3.5 Domestic tourism demand in selected countries

3.6 Domestic and international tourism demand in selected industrialised and developing countries, 1991

4.1 Trends in the capacity of hotels and similar establishments worldwide, 1985-92

4.2 Trends in the capacity of hotels and similar establishments in Europe, 1985-92

4.3 Trends in the capacity of hotels and similar establishments in the Americas, 1985-92

4.4 Trends in the capacity of hotels and similar establishments in Africa, 1985-92

4.5 Trends in the capacity of hotels and similar establishments in East Asia and the Pacific (EAP), 1985-92

4.6 Trends in the capacity of hotels and similar establishments in South Asia, 1985-92

4.7 The twenty largest hotel groups

4.8 Resort timesharing market by area of world, end 1991

4.9 Top 30 restaurant chains in the USA classified by number of units

4.10 Top 25 holding companies in the USA classified by number of units

5.1 Average growth rate of air transport demand, 1981-90 120

5.2 The international air transport market, 1990

5.3 The world's busiest routes (scheduled traffic), March $1993 \quad 125$

5.4 Airline performance (revenue passenger kilometres), $1993 \quad 126$

5.5 Airline performance (turnover), 1993

5.6 Airline performance (profitability), 1993

5.7 European airlines: winners and losers 129

5.8 Airline operating cost distribution, ICAO Airlines, $1991 \quad 135$

5.9 Workforce of the top airline companies, $1993 \quad 135$

5.10 Number of aircraft in airline fleets (Jets and Turbo), $1992 \quad 136$

5.11 Global alliances, mergers and partnerships 148

5.12 Alcazar (failed alliance) 149

5.13 Public sector ownership of selected airline companies in Europe

5.14 Regional breakdown of scheduled traffic, 1981-90 159

6.1 The changing profile of the tour operator market in the UK 170

6.2 The largest tour operators in France 177

6.3 Package tour costing example 184

6.4 Cost elements of an organised trip 184

6.5 Tour operator profit margin 185

7.1 Forecast operating account 196

8.1 Employment in the tourism industry 222 
8.2 Ratio of receipts in the travel account of different countries compared with their GNP

8.3 Tourism receipt multiplier

8.4 Importance of trade in tourism

8.5 Imports in tourism consumption

8.6 Tourism balances in OECD countries

9.1 Promotional budgets of national tourism administrations in the Americas, 1993

10.1 State and private sector contributions to the Maison de le France, 1990-2

10.2 Comparison of national funding levels in Britain 308

11.1 The developing countries, 1991

$\begin{array}{lll}11.2 & \text { International tourist arrivals } & 317\end{array}$

12.1 World tourism growth trends and forecasts 338

12.2 Trends in regional market share, 1970-2010 339

12.3 Forecast of tourist arrivals worldwide from five major generating markets, 1990-2010 340

12.4 Tourism growth trends and forecasts in Europe 341

12.5 Tourism growth trends and forecasts in the Americas 343

12.6 Tourism growth trends and forecasts in East Asia and the Pacific 


\section{List of Figures}

1.1 Classification of international visitors 5

1.2 Establishing a system of tourism statistics 10

1.3 Breakdown of arrivals by mode of transport, 1985-92 16

1.4 Development of international tourism worldwide, 1970-93 17

1.5 Share of each region in total international tourist arrivals and receipts worldwide, 1993

2.1 International tourist arrivals in Europe by country of origin, 1985-92

2.2 Development of international tourism in Europe, 1970-93 30

2.3 Share of each sub-region in total international tourist arrivals and receipts in Europe, 1992

2.4 International tourist arrivals in the Americas by country of origin, 1985-92

2.5 Development of international tourism in the Americas, 1970-93

2.6 Share of each sub-region in total international tourist arrivals and receipts in the Americas, 1992

2.7 International tourist arrivals in Africa by country of origin, 1985-92

2.8 Development of international tourism in Africa, 1970-93 41

2.9 Share of each sub-region in total international tourist arrivals and receipts in Africa, 1992

2.10 International tourist arrivals in the Middle East by country of origin, 1985-92

2.11 Breakdown of arrivals in the Middle East by mode of transport, 1985-92

2.12 Development of international tourism in the Middle East, 1970-93

2.13 International tourist arrivals in South Asia by country of origin, 1985-92

2.14 Development of international tourism in South Asia, 197093

2.15 Breakdown of arrivals in South Asia by mode of transport, 1985-92

2.16 Breakdown of arrivals by international tourists in East Asia and the Pacific by country of origin, 1985-92

2.17 Development of international tourism in East Asia and the Pacific, 1970-93 
2.18 Share of each sub-region in total international tourist arrivals and receipts in East Asia and the Pacific, 1992

3.1 Factor endowment model

3.2 Endowments and production

3.3 Factor intensity and specialisation $\quad 72$

4.1 Market share of the top 100 by sector 115

5.1 Air traffic trends according to major regions, 1971-90 123

5.2 Annual growth in air travel (RPK) 124

5.3 Major air travel markets, 1994-2013 124

5.4 The fifth freedom of the air 138

5.5 Cabotage 139

6.1 The cruise industry: world passenger volume, 1980-96 166

8.1 The tourism multiplier 230

8.2 The main occupations of local population on 70 world heritage sites 235

8.3 The impact of tourism on world heritage sites 236

8.4 Balance of payments for tourism 249

8.5 Percentage of deficit and surplus for tourism, $1990 \quad 250$

9.1 Breakdown of missions and projects by region, 1980September $1992 \quad 262$

10.1 International tourism receipts 294

11.1 Carrying capacity of a destination 326

12.1 International tourist arrivals worldwide: trends and prospects, $1950-2010$

12.2 Growth of international tourist arrivals worldwide by region of origin

12.3 International tourist arrivals in Europe: trends and prospects, $1950-2010$

12.4 International tourist arrivals in the Americas: trends and prospects, $1950-2010$

12.5 Americas - forecasts of inbound tourism by sub-region, 1990-2010

12.6 International tourist arrivals in East Asia and the Pacific: trends and prospects, 1950-2010 


\section{List of Boxes}

1.1 Visitors included and excluded in tourism statistics 6

4.1 RCI holiday exchange 110

4.2 The economic impact of timeshare 111

5.1 Job losses in the airline industry 137

5.2 A failed alliance - Alcazar 149

6.1 Cruising: a new package holiday for the 1990s 166

6.2 The TUI group 176

7.1 An example of investment procedures and incentives:

Western Samoa $\quad 211$

8.1 Training in Romania 224

8.2a The 'Ten Commandments' of protecting World Heritage sites 236

8.2b The World Heritage list 237

8.3 Camino Real: a historic trail 238

9.1 Areas of activity of the WT0 257

9.2 The main points of the Manila Declaration, $1980 \quad 261$

9.3 WTO - international tourism cooperation 261

9.4 GATS and tourism offers 265

9.5 The World Travel Market - a profile 272

9.6 Example of solution for eliminating health risks: the case of British Airways 288

11.1 The problem of communication in developing countries: the case of West Africa $\quad 332$ 


\section{Acknowledgements}

We are very grateful to the World Tourism Organisation for its support and for providing information and statistics. We would particularly like to thank Mr Antonio Enríquez Savignac, its Secretary-General, Mr Francesco Frangialli, the Deputy Secretary General, Mr Enzo Pacci, responsible for statistics, and Dr Eduardo Fayos, Director of Education and Training.

We are also indebted to $\mathrm{Mr}$ Simon Wilde for his guidance on language and style and $\mathrm{Mr}$ Alex Noble, Lecturer in Financial Management at the University of Surrey, for his direction and advice on the section dealing with finance and investment in the tourism industry.

François Vellas

LIONEL BÉCHEREL 


\section{List of Abbreviations}

$\begin{array}{ll}\text { ACP } & \text { Africa, Caribbean and Pacific } \\ \text { ADB } & \text { African Development Bank } \\ \text { ANTO } & \text { Austrian National Tourist Office } \\ \text { BTA } & \text { British Tourist Association } \\ \text { CRS } & \text { Computer reservation system } \\ \text { EDF } & \text { European Development Fund } \\ \text { EFRD } & \text { European Fund for Regional Development } \\ \text { EIB } & \text { European Investment Bank } \\ \text { ETB } & \text { English Tourist Board } \\ \text { EU } & \text { European Union } \\ \text { GATS } & \text { General Agreement on Trade and Services } \\ \text { GATT } & \text { General Agreement on Tariffs and Trade } \\ \text { GDS } & \text { Global development system } \\ \text { GEI } & \text { Grouping of economic interests } \\ \text { IATA } & \text { International Air Transport Association } \\ \text { IATM } & \text { International Association of Tour Managers } \\ \text { IBRD } & \text { International Bank for Reconstruction and Development } \\ \text { IBST } & \text { International Bureau for Social Tourism } \\ \text { ICAO } & \text { International Civil Aviation Organisation } \\ \text { IDA } & \text { International Development Association } \\ \text { IFC } & \text { International Finance Corporation } \\ \text { ILO } & \text { International Labour Office } \\ \text { IMF } & \text { International Monetary Fund } \\ \text { IUOTO } & \text { International Union of Official Tourism Organisations } \\ \text { NITB } & \text { Northern Ireland Tourist Board } \\ \text { NTO } & \text { National Tourist Office } \\ \text { OECD } & \text { Organisation for Economic Co-operation and Development } \\ \text { PATA } & \text { Pacific Asian Travel Association } \\ \text { STB } & \text { Scottish Tourist Board } \\ \text { UNCTAD } & \text { United Nations Conference on Trade and Development } \\ \text { UNDP } & \text { United Nations Development Programme } \\ \text { UNEP } & \text { United Nations Environmental Programme } \\ \text { UNESCO } & \text { United Nations Educational, Scientiic and Cultural } \\ & \text { Organisation } \\ \text { USTTA } & \text { United States Travel and Tourism Administration } \\ \text { WATA } & \text { World Association for Travel Agencies } \\ \text { WHO } & \text { World Health Organisation } \\ \text { WTB } & \text { Welsh Tourist Board } \\ \text { WTO } & \text { World Tourism Organisation } \\ & \end{array}$




\section{Foreword}

After several decades of rapid growth, the tourism industry has reached a critical point in its development. We find ourselves in the midst of a business paradigm shift, where the old rules for profitability and long-term success are losing validity.

The new paradigm is primarily characterised by the supersegmentation of demand, flexibility of supply and distribution, and achieving profitability through system economies instead of economies of scale.

In a mass production system of tourism such as the one which has predominated in the last few decades, the only choice the client had was to consume totally standardised and, hence, very rigidly structured products. However, the new conditions in the market require a far more sophisticated approach.

Certainly, the scenario of the tourism industry for the coming years includes a new map of competitiveness in which enterprises must compete globally, not only within the tourism sector, but often with companies in the larger leisure industry at world level.

In order to do so, businesses and professionals must adapt their skills and strategies (i.e. their culture) to the new market environment by: (i) improving their tourism information systems, to better understand demand requirements and the strategy of the competition, and to communicate the products offered; (ii) improving knowhow acquisition through increased efforts in $\mathrm{R} \& \mathrm{D}$, enabling the most competitive product to be offered at any time; (iii) investing in human capital, streamlining the entrepreneurial culture, which often constitutes the key element for success; and (iv) instilling a philosophy and methodology of total quality in service, in which products and processes are selected by their capability to give satisfaction to consumers.

In this context, International Tourism represents a productive new approach to the knowledge of contemporary tourism in its global perspective. Its authors, Professor François Vellas and Mr Lionel Bécherel, are well known for their significant contributions to tourism research and education. François Vellas has wide experience in teaching tourism in his capacity as Professor of International Economics at the University of Toulouse. He has acted as consultant and adviser on tourism policy matters for the World Tourism Organisation, the Commission of the European Union and many other public and private institutions. He is also the author of numerous publications on tourism and aviation and an active member of prestigious academic associations in tourism. In addition, 
Lionel Bécherel has been very actively involved with the educational undertakings of the Surrey Research Group at the University of Surrey and with tourism departments in the United Kingdom on the local and national level. He has also acted as consultant in several international projects and lectured extensively in tourism, economics and business studies, both in Guildford and at the University of Toulouse.

International Tourism is an ambitious book. With a direct, pragmatic approach, Vellas and Bécherel cover very extensive ground. From basic definitions to predicted trends through demand and supply conditions, marketing, finance, sociocultural and ecological impacts, development issues, and tourism policy. All is here - in clear, concise language; very effective in its descriptive capabilities, and notably able in summarising state-of-the-art tourism knowledge.

I particularly like the treatment of topics not usually analysed in textbooks - for example, the theories of international specialisation (comparative advantage, demand theory, etc.) in their application to tourism, the consideration of the economic and environmental impacts of tourism; the analysis of aviation policies (specifically deregulation in the USA and Europe); and, last but not least, tourism policies in industrialised and developing countries.

The authors are well aware of the ongoing paradigm shift in the tourism industry and the need for a broad, comprehensive view of the main issues at stake - together with a subtle, astute insight of the causes underlying the changes. Hence, the book responds well to the needs of students and professionals in the four above-mentioned areas: information, knowhow, education and total quality management.

While it is true that we cannot always have the future we would like and this is especially certain for our increasingly complex and environment-dependent tourism industry - we can adapt and prepare for the real future. Vellas and Bécherel's book does an excellent job in helping those of us who think and work in one of the most dynamic industries of contemporary society

Director of Education and Training, EdUARdo FAYOS-SOLÁ World Tourism Organisation, Madrid 


\section{Introduction}

There are few economic sectors which generate as much added value, employment and currency for such a low cost as international tourism. All tourism products and services consumed by foreign visitors are exports which avoid the costs of distribution and transport to other markets. International tourism both provides foreign currency and distributes purchasing power throughout the visited country.

Tourism has become the world's most important economic activity.

- According to the World Tourism Organisation (WTO), annual expenditure worldwide on tourism is more than 2,000 billion US dollars (of which US\$324 billion is attributed to international tourism). In 1994, tourism accounts for 12 per cent of the world's Gross National Product (GNP).

- The travel and tourism industry has become the principal source of job creation in many countries and employs more than 100 million people worldwide.

- The economic impact of the industry has been considerable. It is responsible for approximately 7 per cent of global capital expenditure.

International tourism not only influences economics, it also affects social, environmental and land development policies.

Although vast tourism movements are a recent phenomenon, they actually reflect a long tradition of migrations and mixing of populations. Nowadays, these population movements are not just confined to certain regions. They affect virtually every country in the world, either as tourist receptors or tourist generators or both. Even today, international tourism is transforming previously closed societies of insular inward-looking states into an open universal society where contact between peoples becomes a daily reality. It satisfies a deep need for encounters and exchanges with other cultures, for escape, health and social progress. It is undeniably one of the most influential phenomena (possibly even the most influential) in the economic and social development of our society.

However, the growth of international tourism also creates a number of difficulties which can cause severe crises. These have led to questions from certain quarters about its social, cultural and even economic consequences. In contrast to the positive effects on employment and the production of revenue are some strong negative effects: inflation, the destruction of the environment and of the traditions of local populations. These are 
particularly sensitive issues in developing countries, where tourists from industrialised countries impose, by their very presence, a way of life and a level of consumption which can often offend local sensibilities. Similarly, in certain regions, particularly the European Mediterranean, high tourist concentrations, resulting from uncontrolled development, contribute to the destruction of the economic and social fabric as well as the cultural heritage of the local population.

It is therefore imperative to assess not only the contribution of international tourism but also its consequences, in order to increase the advantages that it brings and avoid its damaging effects. This is the objective of economic and international tourism policies.

The economic approach to international tourism is based on a methodology which uses the knowledge and techniques of economic analysis to design and implement policies adapted to its needs. First, the methodology requires an in-depth understanding of tourism activity, followed by the economic analysis of this activity and, finally, the communication of the results to decision-makers in both the public and private sectors, so that tourism policies can be developed and implemented at local, national and international levels.

The in-depth understanding of tourism activity concerns both the international tourism flows of populations and the financial flows of currency in and out of countries, as well as the impacts of these flows on national economies. Additionally, it involves an understanding of sectors of economic activity which depend partially or totally on tourism, such as transport (in particular, air transport), accommodation (the hotel and catering industries), the commercial sector (travel agencies and tour operators), administrative services and international tourism organisations.

The economic analysis of tourism activity focuses on the determinants of international tourism and on its economic mechanisms. The methodology uses techniques of international economics based on the theory of international exchange in conjunction with empirical studies and the analysis of case studies. This approach analyses the causes of international tourism by evaluating the role of the determinants of exchange (factor endowments, comparative costs, absolute advantages, representative demand). The economic analysis is also applied to the mechanism which spreads the receipts generated by international tourism throughout the economy, using the tourism foreign account system and the multiplier techniques.

Tourism policy is a result of actions planned at local, regional, national and international levels, and its analysis determines the necessary level of intervention by the public authorities. In industrialised countries, decentralisation has resulted in a development of tourism better adapted 
to the needs of the population of each region. In developing countries, tourism development programmes set up with the financial and technical help of international organisations have resulted in regional planning. This has reduced the financial burden on developing countries and increased the profitability of tourism infrastructures that have been created.

Tourism policy must take into account a number of external variables such as demographic and social change; the economic and financial situation of generating countries; currency exchange-rate fluctuations; political, legal and statutory change; technological progress; shifts in trading patterns; transport infrastructure; the security of travellers; and the protection of sites and the environment.

Three determinants affecting tourism play a particularly significant role in the evolution of international demand in industrialised countries:

1. Demographic changes and social evolution;

2. Increased leisure and holiday time;

3. Fragmentation of holidays and market segmentation.

\section{Demographic changes}

By the year 2000 there will be more than 144 million Europeans aged between 35 and 45 years. This is 16 per cent more than in 1985 . The over65 -year-old age group will have increased by more than 14 million people (from 61 million to 75 million) in the same period.

The 35- to 54-year-olds generally enjoy the highest disposable income and this group is increasing at a faster rate than any other age group - a very favourable situation for the future expansion of the industry.

Nowadays, over $65 \mathrm{~s}$ also have higher incomes and more free time. Furthermore, older travellers are more flexible with their time and can travel during offpeak periods, thus contributing to a longer tourism season.

\section{Increased leisure and holiday time}

The working population of industrialised countries is enjoying increased leisure time and more holidays. Although this is common to all industrialised countries, there are significant differences between nations. For example, the length of the annual paid holiday in the United States and Japan is generally less than a month and sometimes just a fortnight. Western European workers are entitled to longer paid holidays. France, in particular, allows its workforce five weeks of statutory annual paid leave. If national holidays are included, the French enjoy up to eight weeks of paid vacation a year. 
3. The fragmentation of holiday time

This is a direct consequence of the increase in available holiday time. Now that total annual holiday periods are longer, the traditional 'four-week holiday' is disappearing. Tourists are abandoning the concept of the onemonth vacation and replacing it with several shorter breaks of one to three weeks spread over the year.

The international market has been transformed by this fragmentation and increase in the number of holidays. New products are being created for each market segment to satisfy the demand for shorter breaks. The family holiday and the traditional rest and relaxation holiday, based solely on bed and board, no longer meets the requirements of today's tourist.

As a result, industrial and commercial strategies, adapted to the new conditions of the market, need to be developed and implemented.

The aim of this book is to contribute to the understanding of the economic factors and agents which create international tourism and to relate the reasoning, techniques and processes adopted by professionals, administrators and politicians who have particular responsibility for developing and evaluating tourism programmes and policies. 